\title{
ABECE: An Application for Initial Literacy though the Phonic Method
}

\author{
Vilson Soares de Siqueira ${ }^{1,2 *}$, Pedro Araújo Cortez ${ }^{1}$, Juçara Kelly Coelho Sobrinho Galvão ${ }^{1}$, \\ Marcelo Lisboa Rocha ${ }^{2}$ \\ ${ }^{1}$ Federal institute of Tocantins, Araguatins, Brazil. \\ 2 Federal University of Tocantins, Palmas, Brazil. \\ * Corresponding author. Tel.: +55 63 8474-3380; email: vilsonsoares@ifto.edu.br \\ Manuscript submitted August 30, 2015; accepted March 22, 2016.
}

doi: 10.17706/ijeeee.2016.6.2.84-90

\begin{abstract}
The aim of this paper is to present the ABECE application, which is a support tool for teacher and pupil in teaching and learning the phonic method. The phonic method is a method of literacy who first teaches the sounds of each letter and then builds mix these sounds together to achieve the full pronunciation of the word. Allowing this way you be able to read any word. The application was based on reading and writing model proposed by Frith, explained and expanded by Capovilla, where there were enumerated three stages to the process of learning the reading and writing for children, namely: the logographic, the alphabetic and the orthographic. The application can be installed on smartphones and tablets with Google Android Operating System and is available free in the Google Play Store.
\end{abstract}

Key words: Alphabetic, logographic, phonic method, orthographic.

\section{Introduction}

The Information and communication technologies (ICT) are increasingly in the school environment, such as interdisciplinary way to support teaching. Among them stand out the use of applications, to awaken the playful way to improve teaching and learning.

In teaching the early grades is no different, the children in the middle of contemporary age are increasingly connected to the familiarity with smartphones and tablets. Accordingly, a variety of applications and teaching material are being introduced in order to contribute to the teaching.

Oliveira, Sacchetto, Ueki, Silva and Macedo [1] conducted an intervention in dyslexic children using a computer literacy phonics software and achieved significant results in the writing of words. Further emphasized with its results that you need to apply activities in order to develop the orthographic writing skill.

Justino and Barrera [2], conducted an intervention based on phonics approach, using pre-test and post-test outlining, in order to compare the knowledge of phonological awareness, letter knowledge, reading and writing. The statistical results showed satisfactory results.

The present work presents an application entitled "ABECE" developed for smartphones and tablets with Google Android Operating System. The objective of this work is to disseminate the application that has the purpose of act as a support tool for the teacher and student in the teaching process and learning the phonic method. The application brings innovation to the teaching of the phonic method, through the use of voice and voice command Google Now assistant, available since version 4.1 of the Google Android Operation 
System.

\section{Literature Review}

Order to understand how the systematic instructions graph-phonemic matches and the development of phonological awareness can contribute to the competence of reading and writing construction, it was necessary to conduct a literature review.

The research approach is relevant as it the utilization of the phonic method in literacy is a subject of several theoretical discussions, both in the area of psychology as Education. Therefore, the results can provide subsidies for school activities that can effectively contribute to overcoming the difficulties of literacy in Brazil.

\subsection{The Literacy Process}

The literacy process can be facilitated when children enter school with some informal experience of written language learning, where they can differentiate their social use, its relevance and its affinity with orality [3]. The traditional ways of literacy in versions synthetic, analytical and analytical-synthetic or eclectic, were centered in the skills development of coding and decoding [4].

According to Justine [2] the obtained results suggest important relations between letter knowledge and reading and writing learning. Therefore, In effect the study results [5] show that the knowledge of the alphabet has a close correlation with the initial progress in literacy.

As opposed to what is explicitly recommended by countries like the United States, Britain, France, Denmark and others, the Ministry of Education of Brazil, still recommend the global literacy method, which contradicts the evidence of national and international scientific research on literacy[6]. Other countries such as Australia, Belgium, Canada, Cuba, Denmark, Finland, Ireland, Norway and Sweden have also recognized the importance of the explicit teaching of correspondences between graphemes and phonemes to facilitate literacy and decrease the incidence of reading and writing difficulties [6].

In relation to improvement of phonological awareness levels with the intervention, in general the results are in agreement with other authors in the literature as (Bernardino Jr. et al, 2006;.. Paula et al, 2005), which present advances significant in reading, writing and metaphonological skills in students with learning disabilities submitted to training in phonological awareness and the explicit teaching of correspondences between graphemes and phonemes [2].

\subsection{The Reading and Writing Learning}

The reading and writing learning is primarily based on an understanding of the alphabetic principle, which in turn depends on three skills: a) the awareness that you can segment the language spoken into distinct units (phonemes); b) the awareness that these same units are repeated in different words spoken; c) knowledge of rules of correspondence between graphemes and phonemes [7].

It is necessary consider still that phonological awareness is necessary factor, but is insufficient for learning to read and write, which also depends on the development of other metalinguistic skills, such as awareness of morphological aspects and syntactic language, which have shown related to spell competence [8]. In this perspective, reading occurs as a double process model, that is, through two routes, phonological and lexical [9].

\subsection{The Methods of Literacy}

The literacy methods can traditionally be classified into two broad categories: synthetic and analytical. The synthetic methods are going in part to the whole, and the part may be the phoneme (phonic method), the letter (alphabetic method) or syllables. Already analytical methods are going the whole (words, phrases 
or texts) for the parts (syllables and phonemes). In both cases, the emphasis is working with the decoding [10]. For [11] the syllabic method is based ready syllables, which combine to mold words.

According to [11] phonics literacy is made by combining development of phonological awareness exercises and teaching of correspondences between graphemes and phonemes. Procedures to implement the phonic literacy have already been described in several books and articles Brazilians [12]-[13] and [6].

The phonic method is based on phonic and metaphonological instructions, in order to review an explicit and systematic teaching of graphphonemic correspondences, and in parallel induces the development of metalinguistic skills, that is, of phonological awareness [6].

In [14] presents three existing strategies for dealing with the written word. At first, the logographic, reading and writing are still incipient, for characterized by the use of contextual clues and non-linguistic, the same way as the colors, the background and the overall shape of words. In alphabetical strategy, with increasing phonological route, the child learns the rules of graph-phonemic correspondences. The orthographic strategy, in turn, is characterized by direct visual processing of words, that is, the child already has a spelling mental lexicon and, from this orthographic representation, has direct access to semantic system.

According to [6], it is also important to consider the hypothesis that phonic methodologies, aimed at the explicit teaching of the relationship between letters and sounds and the development of phonological awareness, are more efficient for the acquisition of the alphabetic principle in more transparent languages such as the if the Portuguese, than in other less regular as French and English.

In [12] analyzing countless studies with very satisfactory results that point the phonic method as the most suitable to remedy delays or difficulties in reading and writing, contributing to prevent and remedy the failure in literacy, some institutional bodies from countries such as United States, France and Britain are rescuing the importance of phonics instruction as an essential part of their literacy proposals.

\section{Methodology}

It was initially performed an Literature Review on the teaching of phonic method, which allowed to obtain characteristics to develop the application functions to support the teaching and learning of phonic method.

It was followed by some important principles, the main one is that it should be based not only on computational concepts, but also in educational techniques to let the well defined pedagogical proposal, for that with the application's usability is relevant to support from the teaching method phonic.

For application development we used the development platform of the Massachusetts Institute of Technology, MIT inventor app, developed under the open source license and is available on site, http://appinventor.mit.edu/explore/, which has the aim building applications for the Google Android Operating System quick and easy way, the platform provides the developer the use of all native functions and resources of the Operation System. Among the top features that have been implemented in the development of the proposed application stand out, Android's voice assistant and voice command assistant Google Now, which was made available from version 4.1. The license to use political and distribution of ABECE application is free.

\section{Results and Discussion}

The ABECE application was based and adapted by reading model proposed by [14] explained and expanded by [12] and [13]. Where they were enumerated three stages to the process of reading and writing learning in literacy of children, namely:

1) The logographic, in which it treats the written word as if it were a pictoideographic and visual 
representation of the referent;

2) The alphabetic, where, with the development of route phonological, the child learns to do graph phonemic decoding;

3) The orthographic, that with the development of lexical route, the child learns to make direct visual reading the high frequency words.

\subsection{The ABECE Application}

For the applicability of the model, the ABECE application presents in its main window, their functions divided in two modules, which been added three icons to access the modules, see in Fig. 1. The Module I functions, represent stages one and two which are the logographic and alphabetic. The module II functions represent the three stage, which is the orthographic. The Module III is presented in a drawing tool.

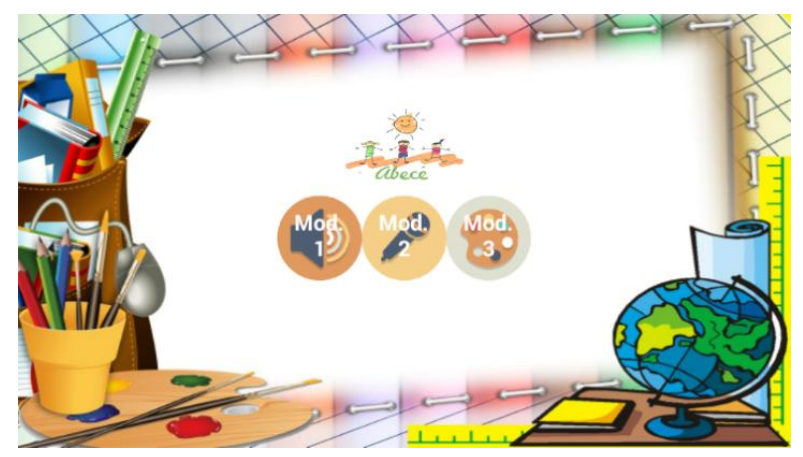

Fig. 1. ABECE - Main screen

\subsection{Module I}

Vowels, Consonants and alphabet: The app features the vowels, consonants and the alphabet, with four forms of writing, with calligraphic letters and letter-shaped in lowercase and uppercase. Also brings the syllabic method and phonic method with its graphemes and phonemes. As seen in Fig. 2 and Fig. 3.

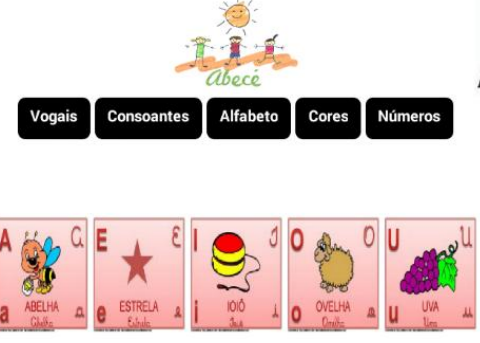

Fig. 2. The vowels screen.

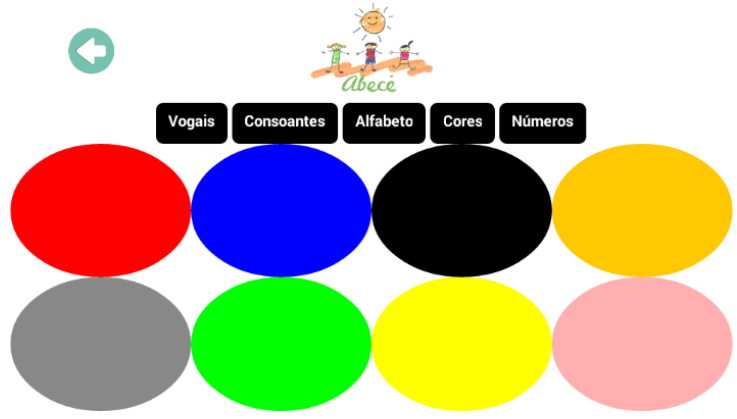

Fig. 4. The colors screen.
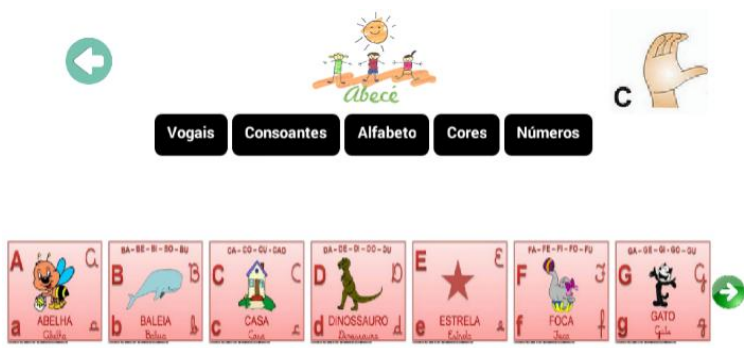

Fig. 3. The alphabet screen.

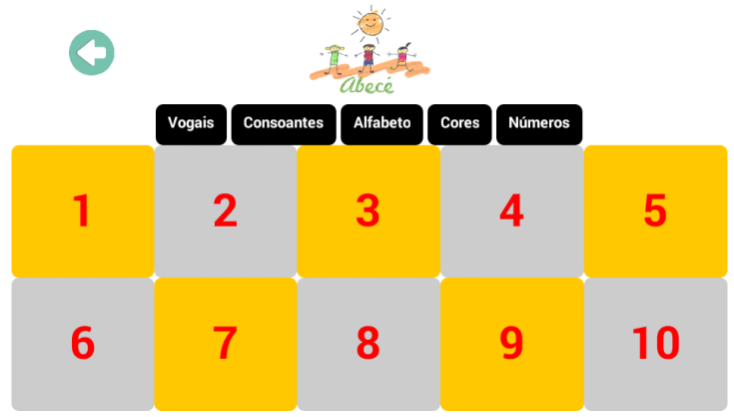

Fig. 5. The numbers screen. 
Color: In this section, the colors are presented. Also brings phonic method with color and phonemes. Aims to teach the colors when the child touches the corresponding circles the color, the application responds through the Google voice assistant, which was the touched color. This makes the child associates talking with the color texture. See Fig. 4.

Numbers: This section provides the numbers 1-10, with phonic method of numbers, graphemes and phonemes. Featured in Fig. 5.

LIBRAS: The application shown in sections vowels, alphabet and numbers, representing the Brazilian Sign Language (LIBRAS) for vowels, consonants and numbers. In this context, we emphasize the importance of systematic and persistent struggle of people with hearing impairment, it was recognized by the Brazilian nation as the Official Language of the Deaf person, with the publication of Law №. 10.436, of 2002.04.24. and Law №. 10.098, of 2002.12.19 [15].

\subsection{Module II}

Speak the Word: this is an application interactivity resource, with it's possible the child speak using Android's voice command and the application returns the spelling of what was spoken. In this way, the teacher and student can assess whether the pronunciation of what was spoken is correct. Thus, it can be worked errors of pronunciation and speech. See in Fig. 6.

Write Word: This option gives opportunity the child to practice writing the word that was spoken or any other word. For this one can use touch pen, touch screen displays or to use the finger to realize the word writing process. See Fig. 7.

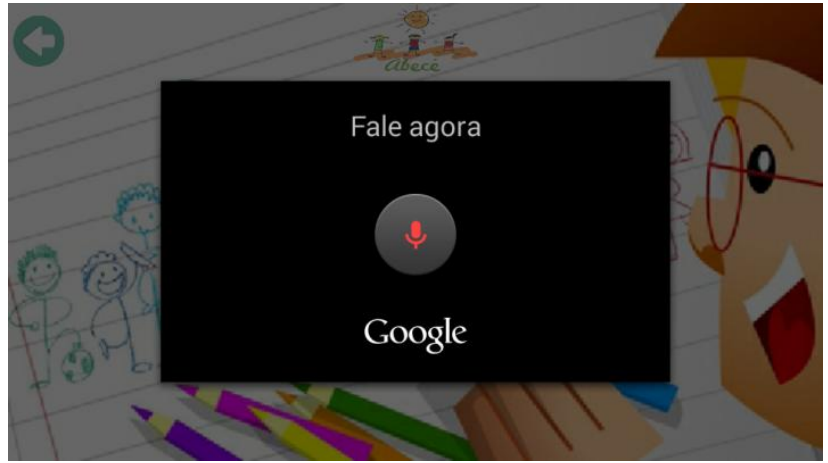

Fig. 6. The screen speak the word.

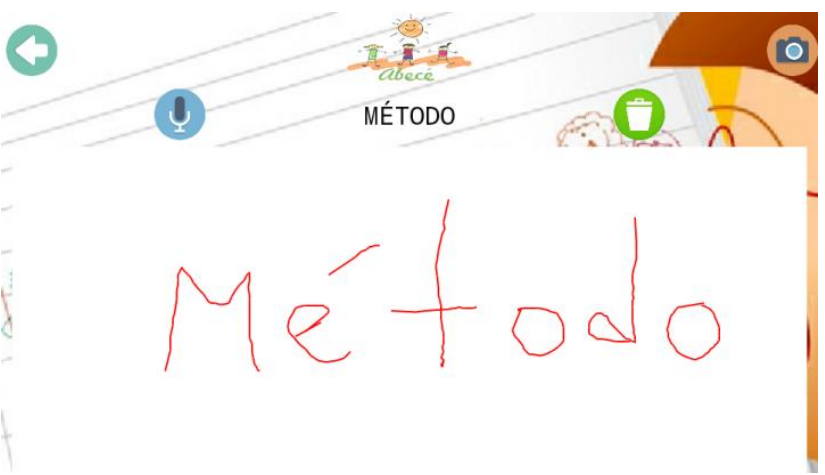

Fig. 7. The screen write the word.

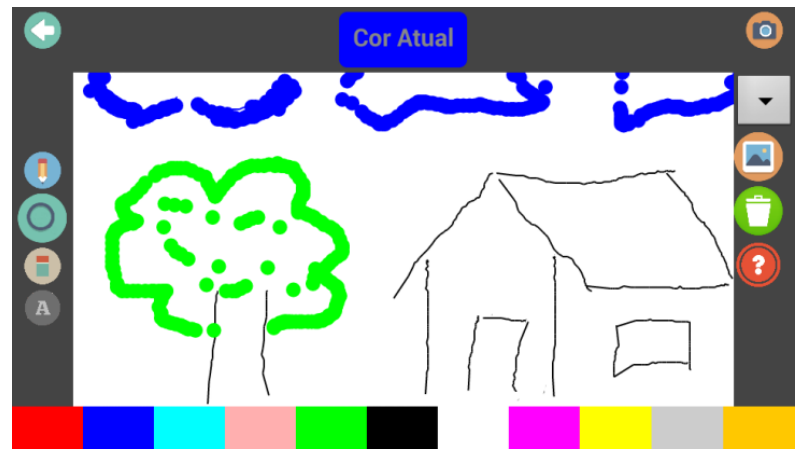

Fig. 8. Drawing tool.

\subsection{Module III}

The drawing tool is aimed at awaken the creativity of children. It is possible to make drawings using 
colors. Its main features are clear screen, rubber, pencil with several line widths, insert text, color images and at the end can do a print screen of what was drawn. See Fig. 8.

The ABECE application is available for free download in Google Play Store https://play.google.com/store/apps/details?id=appinventor.ai_PCortez187.Abece\&hl=pt_BR.

It can be installed on smartphones and tablets with Google Operating System Android with versions greater than 4.1 .

\section{Conclusion}

According approach presented in the previous section, this app can be a great ally to support the teacher and student in the teaching and learning of the phonic method. Furthermore, becomes the playful process, regarding the early literacy process.

In this way, we are in the expectation that the application will contribute a significant way to the teaching of initial literacy, using the phonic method.

\section{Acknowledgment}

This work is supported by the Institutional Scholarship Program for Initiation the Teaching of Higher Education Personnel Improvement Coordination, the Ministry of Education of Brazil.

\section{References}

[1] Oliveira, D. G. D., Sacchetto, K. K., Ueki, K., Silva, P. B. D., \& Macedo, E. C. D. (2011). Análise da produção escrita de crianças com dislexia do desenvolvimento submetidas a intervenção fônica computadorizada. Revista Psicopedagogia, 28(87), 246-255.

[2] Justino, M. I. S. V., \& Barrera, S. (2012). Efeitos de uma intervenção na abordagem fônica em alunos com dificuldades de alfabetização. Psicologia: Teoria e Pesquisa, Brasília, 28(4), 399-407.

[3] Cárnio, M. S., \& Santos, D. D. (2005). Evolução da consciência fonológica em alunos de ensino fundamental. Pró-Fono Revista de Atualização Científica, 17(2), 195-200.

[4] Mortatti, M. D. R. L. (2004). Educação e letramento. SCIELO-Ed. UNESP.

[5] Cardoso-Martins, C., Corrêa, M. F., \& Marcheti, P. M. T. (2008). 0 conhecimento do nome das letras e o desenvolvimento inicial da escrita: o caso do português do Brasil. Desenvolvimento da Linguagem Oral e Escrita, 137-153.

[6] Capovilla, A. G. S., \& Capovilla, F. C. (2004). Alfabetização: Método fônico. Memnon.

[7] Byrne, B., \& Fielding-Barnsley, R. (1989). Phonemic awareness and letter knowledge in the child's acquisition of the alphabetic principle. Journal of Educational Psychology, 81(3), 313.

[8] Meireles, E. D. S., \& Correa, J. (2005). Regras contextuais e morfossintáticas na aquisição da ortografia da língua portuguesa por criança. Psicol. Teor. Pesqui, 21(1), 77-84.

[9] Ellis, A. W., \& Young, A. W. (2013). Human Cognitive Neuropsychology: A Textbook with Readings. Psychology Press.

[10] Brasil. (2007). Alfabetização Infantil: Os Novos Caminhos. Relatório Final.

[11] Medeiros, T. G. D., \& Oliveira, E. R. C. (2008). A influência da consciência fonológica em crianças alfabetizadas pelos métodos fônico e silábico. Rev. CEFAC, 10(1), 45-50.

[12] Capovilla, A. G. S., \& Capovilla, F. C. (2000). Problemas de leitura e escrita: como identificar, prevenir e remediar numa abordagem fônica. São Paulo: Memnon.

[13] Capovilla, A. G. S., \& Capovilla, F. C. (2000b). Efeitos do treino de consciência fonológica em crianças com baixo nível socioeconômico. Universidad Federal do Rio Grande do Sul.

[14] Frith, U. (1985). Beneath the surface of developmental dyslexia. Surface dyslexia, 32. 
[15] Federal, S. (2006). Língua brasileira de sinais "uma conquista histórica". Senado Federal Secretaria Especial de Editoração e Publicações. Brasília, OS.

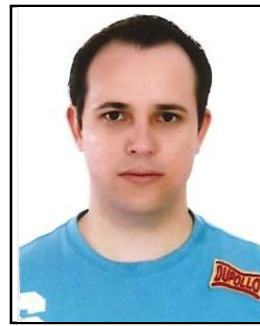

Vilson Soares de Siqueira graduated in information systems the State University of Goias (2008). He is specialization in computer networks for Anhanguera Faculty of Anapolis (2010). He was a master student in computational modeling and systems at the Federal University of Tocantins (2013). He is currently a professor of computer science in Federal Institute of Tocantins, Campus Araguatins, Brazil and computing project area coordinator, the institutionally scholarship program for initiation to teaching, the Federal Institute of Science and Technology Tocantins, Brazil.

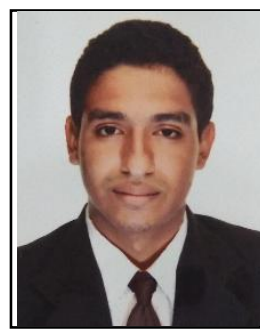

Pedro Araújo Cortez is a computing graduation student at the Federal Institute of Tocantins, Brazil. Currently he works in the area of analysis and development of mobile systems. He is one member of Systems Development Group IFTO campus Araguatins.

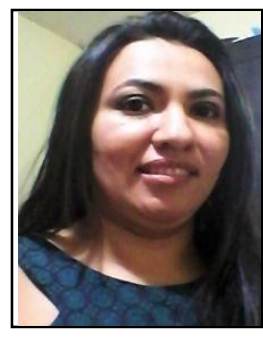

Juçara Kelly Coelho Sobrinho Galvão is a computing graduation student at the Federal Institute of Tocantins, Brazil. Currently she works in the area of analysis and development of mobile systems. She is one member of Systems Development Group IFTO campus Araguatins.

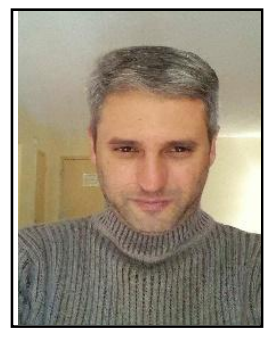

Marcelo Lisboa Rocha is graduated in computer science from the Catholic University of Petropolis (1994). He was a master in computer science from Federal University Fluminense (1997), master in electrical engineering from the Federal University of Rio de Janeiro (1999) and doctorate in electrical engineering from the Federal University of Rio Janeiro (2008). He is currently one reviewer the periodic INFOCOMP Journal of Computer Science and associate teacher 4 of the Federal University of Tocantins, Brazil. He has experience in computer science, acting on the following topics: metaheuristics, combinatorial optimization, mathematical programming, computer networks and high-performance computing. 